\title{
Submental method for orotracheal intubation in treating facial trauma
}

\author{
Maxillofacial Surgery Division, Face and Neck Discipline, \\ Surgery Department and Anesthesiology Department, \\ Faculdade de Ciências Médicas de São Paulo - São Paulo, Brazil
}

\begin{abstract}
Objective: To demonstrate an alternative method for intubating patients with fractures of maxilla and nose, prior to surgery. Design: Cases Report. Participants: We studied 10 patients with facial fractures that affected maxilla and nose. Intervention: The patients were submitted to surgery under general anesthesia and submental oro-tracheal intubation. Results: This type of intubation allowed the surgical team to work on the whole face of the patient and left no visible scar. Conclusion: This procedure is indicated for patients with fractures of maxilla and nose who need surgical intervention under general anesthesia.
\end{abstract}

Uniterms: Intubation. Facial fractures. Nasal surgery. Maxillary surgery.

\section{INTRODUCTION}

$\mathrm{F}$ acial surgery, and particularly maxillofacial surgery, presents peculiar features in relation to general anesthesia, and surgeons and anesthesiologists are at present facing controversies regarding these points of common interest. In such surgery there is a frequent need for maxillo-mandibular fixation (MMF) and a consequent concern that patients in post-anesthesic recovery may vomit and aspirate gastric content which may give rise to significant pulmonary infection.

Intra-operative dental occlusion surgery requiring procedures in the oral and nasal regions (as in the cases of Le Fort II and III fractures), or the impossibility of nasal intubation due to septonasal disorders, may necessitate alternative solutions in addition to those already known.

The correction of maxillar and mandibular fractures has the aim of restoring deformities both esthetically and

\section{Address for correspondence:}

Luiz Carlos Manganello-Souza

Rua Itapeva 500, conj.1-C.

São Paulo/SP - Brasil - CEP 01332-000 functionally, including normal dental occlusion. When a stable relation between the maxilla and mandible is obtained, the surgery is considered sucessful, with dental occlusion as a basic parameter.

Currently, surgeons are using osteosynthesis by means of mini-plates or even screws to fix the fractures, in a method known as Rigid Internal Fixation. ${ }^{1,2}$ Thus, there is no need to immobilize the mandible to the maxilla, contrary to steel wire osteosynthesis cases, ${ }^{3}$ in which this fixation becomes necessary.

Nasotracheal intubation ${ }^{4}$ is indicated in these patients so that the surgeon can have adequate guidance during the intra-operative period and can check the patients' dental occlusion, i.e. the inter-cuspidation of the mandibular teeth with the maxilla teeth, in a complete and correct way.

It is important to note that even if the patient is not going to remain with MMF after surgery, it is necessary during the surgery so that the surgeon has free access to the mouth to check the dental occlusion. ${ }^{1,5,7}$

There are patients who require surgical access for checks on both dental oclusion and the nasal region (e.g. Le Fort II and III), and in these patients nasotracheal intubation may be used, being exchanged for orotracheal intubation later. ${ }^{8}$ 


\section{Surgical Technique}

The technique consists of:

1) Orotracheal intubation (Fig. 1).

2) Cutaneous incision in the submental region, dissection of subcutaneous cellular tissue and of the myo-hyoid muscle on the mouth floor, incision in the mouth floor mucosa and careful dissection so as not to damage the submandibular gland duct (Fig. 2).

3) The tracheal tube is introduced through the submental region and then via the mouth to the trachea, allowing the upper and lower teeth to be occluded during the surgery (Fig. 3).

This technique was used in ten patients with facial trauma, presenting complex naso-ethmoid and maxillary fractures (Figs. 4a, 4b, 4c).

Two patients evolved skin infections that were treated successfully with local measures. The scar was inconspicuous in all patients and none of them complained of it. There were no salivary gland problems.

\section{DISCUSSION}

In cases requiring simultaneous surgical access for checks of dental occlusion and of the nasal region, exchanging nasotracheal for orotracheal intubation becomes necessary. This practice has the disadvantage of allowing the patient to aspirate at the moment of the tube change, which frequently interferes in the surgical procedure.

The use of the submental orotracheal method offers an alternative that the surgeon can use successfully. The submental route does not leave noticeable scars, as the cutaneous incision is made in the submental region, without subsequent occurrence of fistula. Local infection may occur but can easily be treated with no sequelae.

A good relationship between the surgeon and the anesthesiologist is very important in facial surgery, especially oral-maxillary, as this often involves MMF. The surgeon contributes to positive results by applying appropriate techniques and adopting alternative methods to reduce or prevent morbidity.

We feel that leaving the tube away from the surgical field facilitates surgery when compared to nasal intubation, but that this is a procedure that should only be used in very exceptional cases.

In some cases of simultaneous oral-nasal surgical access, ${ }^{2}$ the anesthesiologist is requested to change from

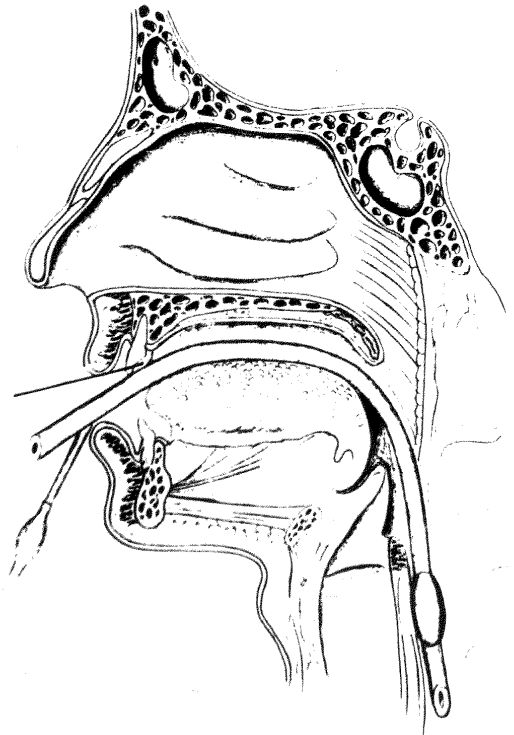

Figure 1- Orotracheal intubation.

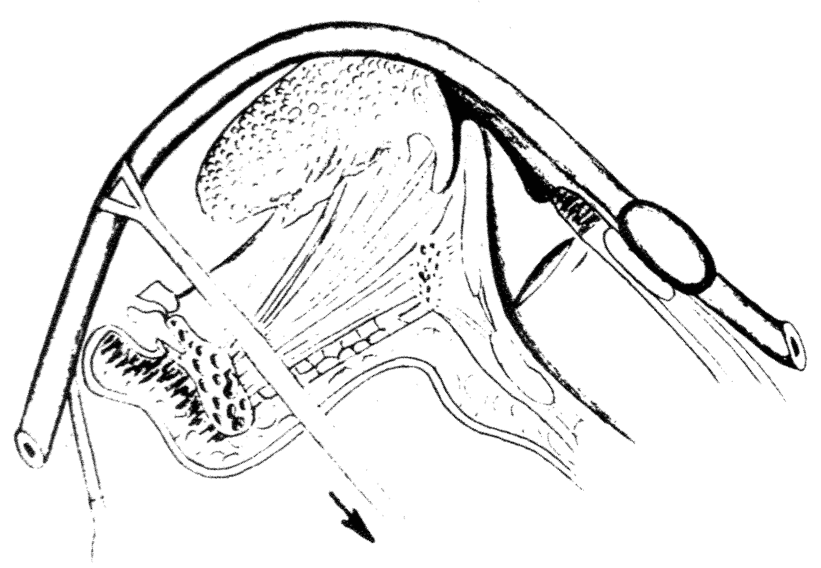

Figure 2- Maneuver to pull down the tube.

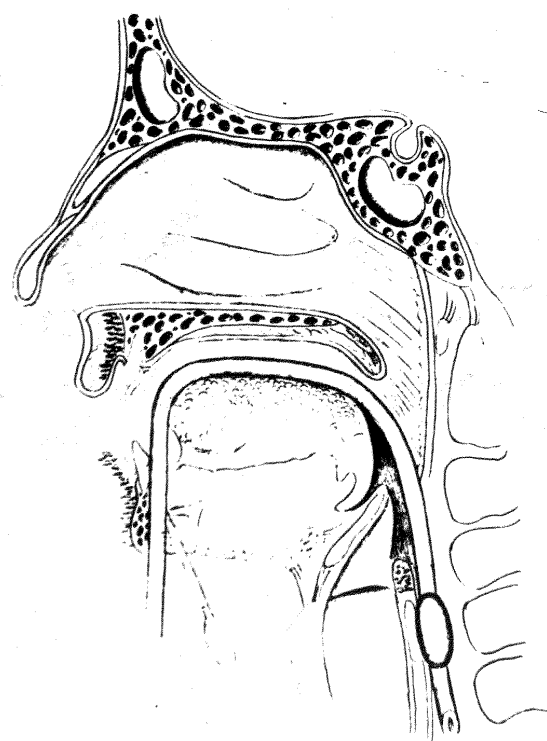

Figure 3- Submental orotracheal intubation. 


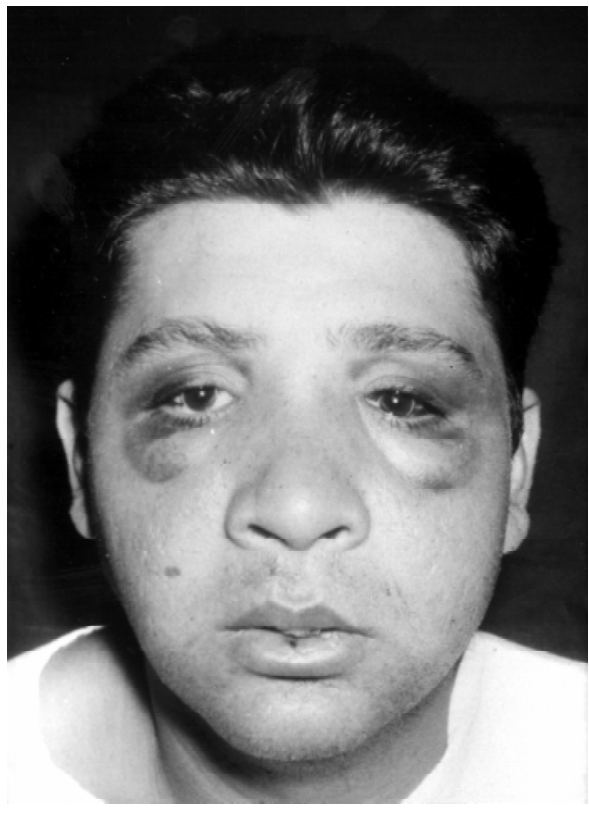

Figure 4a - Patient with naso-maxillary fracture.

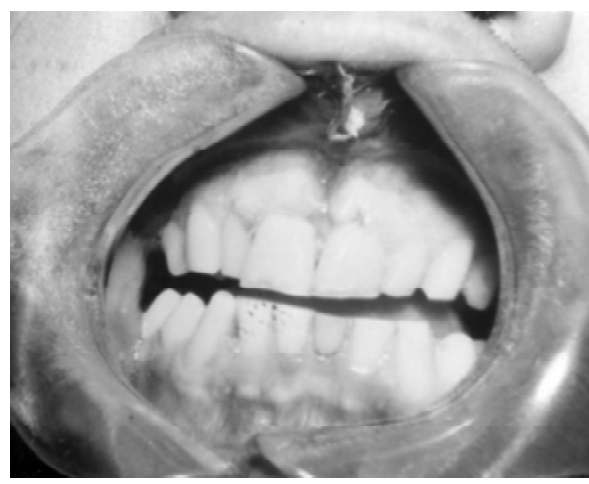

Figure 4b - Patient showing poor occlusion.

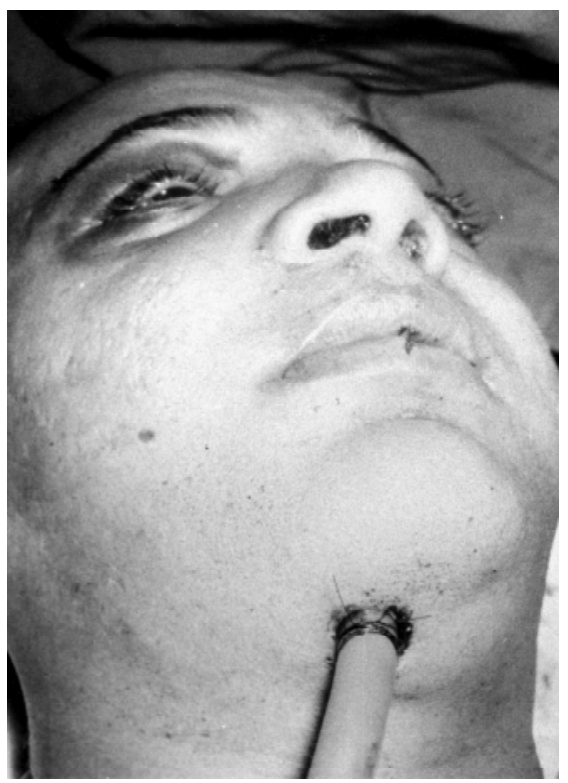

Figure 4c - Patient with submental intubation. nasal to oral intubation. We think that this maneuver (the change from nasal to oral) represents an aspiration risk to the patient. ${ }^{8}$ The submental orotracheal method is very helpful in this kind of surgery. On the other hand, the anesthesiologist contributes to the success of the treatment, preventing complications and discomfort for the patient by performing extubation at the right moment, not allowing the tube to remain longer than necessary, nor extubating before the patient is fully conscious and with protective reflexes restored.

\section{REFERENCES}

1. Manganello-Souza LC, Tenorio-Cabezas N. Miniplacas sem compressão em cirurgia maxilofacial. In: Barros JJ, Manganello LC, editores. Traumatismo buco-maxilo-facial. São Paulo: Roca 1993;389-401.

2. Theriot BA, Van-Sickels JE, Triplett RG, Nishioka GJ. Intraosseus wire fixation versus rigid osseus fixation of mandibular fractures: a preliminary report. J Oral Maxilofac Surg 1982;45:577-82.

3. Rowe NL, Williams LI. Maxillofacial injuries, $2^{\text {nd }}$ edition. London: Churchill Livingstone 1985;456-78.

4. Sinn DP, Hill SC, Watson SW. Mandibular fractures. In: Foster, CA, Sherman JE, editors. Surgery of facial bone fractures. London: Churchill Livingstone 1987;171-94.

5. Mathog RH. Atlas of craniofacial trauma. Philadelphia: Ed Saunders Co 1992;561-76.

6. Hilley MD, Ghali GE, Giesecke AH. Anesthesia for orthognathic and craniofacial surgery. In: Bell HW, editor. Modern practice in orthognathic and reconstructive surgery. Philadelphia: Ed Saunders Co 1992;128-53.

7. Lumsden K, Holden KS. The act of vomiting in man. Gut 1969;10:173-9.

8. Zulian MA, Chisum JW, Mosby EL, Hiatt WR. Extubation criteria for oral and maxillofacial surgery patients. J Oral Maxillofac Surg 1989;47:616-20. 


\section{RESUMO}

Objetivo: Apresentar uma modalidade de entubação oro-traqueal que permita a cirurgia a nível nasal e maxilar, sem comprometer a oclusão dentária. Desenho: Pacientes portadores de fraturas faciais e que necessitavam, no mesmo tempo cirúrgico, do tratamento do nariz e da maxila foram entubados pela via sub mento oro traqueal permitindo a visualização da oclusão dentária e da permeabilidade nasal. Local: Faculdade de Ciências Médicas da Santa Casa de São Paulo, setor de cirurgia maxilofacial, disciplina de cirurgia de face e pescoço, departamento de cirurgia. Participantes: Dez pacientes portadores de fraturas faciais que atingiam o nariz e a maxila. Intervenção: Os pacientes foram operados para redução e fixação das fraturas, sob anestesia geral sob entubação sub mento oro traqueal. Resultados: Este tipo de entubação permitiu o trabalho da equipe cirúrgica em toda a face do paciente, principalmente liberando a via nasal e a oclusão dentária. Conclusão: A via sub mento oro traqueal está indicada sempre que o cirurgião tenha necessidade de fixar fraturas nasais e maxilares no mesmo tempo cirúrgico. 